\title{
Environmental Responsibility Disclosures by Agricultural Companies in Indonesia
}

\author{
Mahardika Putri Prananingrum¹, Arthik Davianti ${ }^{2}$ \\ 1,2 Universitas Kristen Satya Wacana, Salatiga, Indonesia
}

\section{Keywords:}

Environmental Responsibility; Water and Effluent GRI Standard 2016; Agricultural Companies

\section{Kata kunci: \\ Tanggung Jawab Lingkungan; \\ Air dan Limbah; Standar GRI 2016; Perusahaan Agrikultur}

\section{ABSTRACT}

Abstract: This study aims to determine the level of disclosure presented in sustainability reports by seven agricultural companies with a focus on waste and effluents contained based on GRI standards. The study used a qualitative descriptive approach with content analysis and coding sheets. Content analysis will be used by classifying certain criteria based on disclosure groups and coding sheets are used as research instruments to analyze the narrative patterns presented. The results showed that the compliance of effluent and waste in Indonesia's agriculture companies SR is relatively low and not yet detailed. Further, it also suggested that the disclosures are more compatible with the GRI Standard.

Abstrak: Penelitian ini bertujuan untuk mengetahui tingkat pengungkapan yang disajikan dalam laporan keberlanjutan oleh tujuh perusahaan pertanian dengan fokus pada limbah dan efluen berdasarkan standar GRI. Penelitian ini menggunakan pendekatan deskriptif kualitatif dengan analisis isi dan lembar coding. Analisis isi akan digunakan dengan mengklasifikasikan kriteria tertentu berdasarkan kelompok pengungkapan dan lembar kode digunakan sebagai instrumen penelitian untuk menganalisis pola naratif yang disajikan. Hasil penelitian menunjukkan bahwa pemenuhan efluen dan limbah di SR perusahaan pertanian Indonesia relatif rendah dan belum detail. Lebih lanjut, itu juga menyarankan bahwa pengungkapan lebih kompatibel dengan Standar GRI.

Alamat Korespondensi:

E-mail: Prananingrum898@gmail.com (Prananingrum)

\section{Pendahuluan}

Sustainable development is one of the most critical problems in the development process in general, which also applies to companies. The development of the business world makes companies not only focus on the profit they have got. Hence, sustainable development has a vital role in the company activities process (GRI, 2016a). Based on the report of the World Commission on Environment and Development (WCED), sustainable development is stated as "the development that meets the needs of the current generation without compromising the ability of future generation to meet their needs and aspirations" (Visser \& Brundtland, 2013, emphasis in original). Besides, sustainable development has a rapid improvement in companies and organizations because it can be applied in various fields and ensure that companies' activities run ethically and do not damage the environment in the future (Rosen, 2017).

As it is a company's responsibility to implement sustainable development concepts, companies have to apply the practice of reporting information related to their sustainable actions in the form of sustainability reporting using the Global Reporting Initiative (GRI) standard. Global Reporting Initiative standard (GRI) is an independent international organization where GRI's main activity is to develop a reporting framework and achieve transparency in non-financial reporting of the company, with standards and guidelines that have been developed (Bernard et al., 2015). In Indonesia, the Government's implementation of the sustainability report has been supported by issuing several regulations such as Peraturan Otoritas Jasa Keuangan, Lampiran II, NO. 51 / POJK.03 /

$\begin{array}{ll}\text { History: } & \\ \text { Received } & : 4 \text { Februari } 2021 \\ \text { Revised } & : 23 \text { maret } 2021 \\ \text { Accepted } & : 6 \text { April } 2021 \\ \text { Published } & : 25 \text { April } 2021\end{array}$

Publisher: Undiksha Press

Licensed: This work is licensed under a Creative Commons Attribution 3.0 License

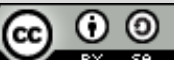


2017 Tentang "Penerapan Keuangan Keberlanjutan Bagi Lembaga Jasa Keuangan, Emiten, dan Perusahaan Publik" bagian Isi Laporan Keberlanjutan $2 b$ tentang "Aspek Lingkungan Hidup", UU Republik Indonesia No. 23 Tahun 1997 tentang "Pengelolaan Lingkungan Hidup", UU Repubik Indonesia NO. 40 Tahun 2007 tentang "Perseroan Terbatas", Pasal 1 bagian 3 tentang "Komitmen Perseroan Terhadap Tanggung Jawab Sosial dan Lingkungan dalam Pembangunan Ekonomi" which is interpreted in the Pasal 66 Ayat $2 c$ tentang "Penyerahan Laporan Tahunan yang Melaksanakan Tanggung Jawab Sosial dan Lingkungan" and Pasal 74 tentang "Tanggung Jawab Sosial dan Lingkungan Perusahaan". GRI, (2016) stated that sustainability reports are an organization reporting practice concerning; economic, environmental, and social impacts. It includes contributions made by the organizations, either positive or negative, for sustainable development. Despite developing countries' awareness of environmental issues, attention to sustainability reports get less attention than developed countries (Alhaj, 2019).

Sustainable reporting is an essential tool used by organizations to show that they are operating responsibly and as a means for civil society to get accountability from the organization (Junior \& Best, 2017). The most commonly used comprehensive sustainability standard in the world was updated and issued by the GRI institution in 2016. The drivers are various issues regarding environmental damage, social problem, and public awareness of the importance of environmental also, company performance has changed people's views about the importance of sustainable reports. This situation makes the stakeholders aware of the concern of sustainable reports on the company. The company is demanded to be more transparent about its performance in ensuring sustainable development. Therefore, there is significant growth in the company in publishing environmental, social, or sustainability reports (Burhan \& Rahmanti, 2012).

In Indonesia, one of the industries that are closely related to the environment and natural resources is the agriculture industry. Agriculture sectors are considered to be relatively attractive to investors both within and outside the country. The perspective is supported by Indonesia's natural potential resources, which are very promising, especially for the agriculture industry. Hence, this sector has a good impact on economic growth in Indonesia. In addition to having a positive impact, this sector also harms the environment. The example was the pollution of one of the rivers in the province of Riau in West Sumatra due to the leakage of a palm oil waste pond, which caused many fish to die, and the river smelled unpleasant (Muryono, 2018). It is suspected that six oil palm companies in Indonesia have problems with forest burning operations that have caused the loss of biodiversity, the primary source of smoke, and the loss of local community land (Primadhyta \& Perkasa, 2018). Also, orangutans' habitat was damaged because of forest fires, and orangutans are considered pests because they eat oil palm shoots (Koesmawardhani \& Wardani, 2017). Based on the many issues that appear in Indonesia's agriculture sector related to environmental issues, it is vital to study whether agriculture companies in Indonesia have reported their environmental issues in a sustainability report that complies with the GRI standards.

Legitimacy theory is one of the theories that is widely used to underlie sustainability report research. This theory will help companies to ensure the communities that companies' activities are suitable. Branco \& Rodrigues, (2006) stated the thing that underlies the legitimacy theory is the existence of "social contracts" that occur between the company and the communities around companies. Thus, the status and operational activities of companies can be considered legal, official, and accepted by outside parties, especially the surrounding community (Amran \& Haniffa, 2011). The legitimacy is intended to deny the problems faced by companies in connection with environmental issues. By publishing a sustainable report, it can help the company prove that the company has carried out social and environmental responsibilities. Besides, there is a tendency of companies to obey the environmental regulations and have an environmentally responsible image that will have an impact on the target market (Ching et al., 2017). Hence, the disclosure of a sustainable report becomes the company's effort to build trust and a positive image in the environment around which the company operates.

Therefore, nowadays stakeholders are increasingly aware of the importance of company information, especially sustainability reports. This awareness makes companies voluntarily publish 
information about their sustainable development on websites or separates reports (Berthelot et al., 2012). Further, Junior \& Best, (2017) found that the Sustainability Report using the GRI standard will help SR stakeholders to improve their understanding of the sustainable report and improve credibility. Hence, the company used GRI Standard in preparing sustainability reports and produced excellent results on reporting, especially for the environment. However, there are still gaps in the results of other studies. Bernard et al., (2015) stated that the GRI standard is not conducive to providing a coherent stakeholder structure, and not all the goals are achieved. Some research on sustainability reporting has been done in Indonesia, such as research conducted by (Almira \& Fuad, 2015; Kurniawan et al., 2018; Tarigan \& Semuel, 2015) using quantitative methods. Therefore, this study would use a qualitative descriptive approach regarding sustainability reporting practices, specifically on reporting relating to environmental issues on effluent and waste, with the GRI standard on agriculture companies in Indonesia. The qualitative approach will be used in this study because it does not focus on numbers or values, and the research object does not depend on numerical measurements.

Based on the background, the problem examined in this study is the environmental issues disclosed in the company's sustainable reports, primarily based on GRI standards. The purpose of this research is to analyze the level of disclosures presented in the sustainability reports by the agriculture companies with a focus on the effluent and waste contained based on the GRI standards to provide benefits to the environment, stakeholders, and the communities around which the company operates. This research will use the GRI standard to indicate how the company's effluent and waste disclosure in its sustainability report. As a guideline for compiling a company's sustainability report, GRI standards will improve the results of the company's SR report. Thus, SR will be well prepared and ensure that the company's effluent and waste of operations are maintained for all parties involved.

This study's results are expected to provide empirical evidence regarding the preparation of sustainability reports by companies from the agriculture sector in Indonesia. Empirical evidence can be used in analyzing or criticizing the preparation of sustainability reports using GRI standards and increased knowledge about sustainability reporting. This study is also expected to be a company reference about the importance of sustainable reporting as a corporate responsibility to the environment and make decisions about the importance of disclosure of sustainability reporting practice. Besides, according to Laoli \& Davianti, (2019) implementing GRI will show how companies make disclosures on the sustainable reporting that the company has prepared. The use of GRI standards will be the company guidelines in preparing a good and organized sustainable report.

\section{Metode}

The purpose of this study is to analyze the suitability level of the disclosure of sustainable reports that have been made by the agriculture companies with a focus on the effluent and waste contained in the GRI Standards. The form of research applied for this research is a qualitative research approach by focusing on document analysis. This research will use companies from the agricultural sector in Indonesia as the research object as explained in the introduction. Thus, this study uses a sample of companies that carried out the selection using a purposive sampling method. This method is used to prevent widespread or biased discussions and more focusing on existing problems.

The criteria for the purposive sampling method in this study are; Indonesian companies in agriculture listed on the Indonesia Stock Exchange (IDX) until 2019, companies that publish sustainability reporting online for 2018 or 2019, both in the form of files that can be downloaded as PDF files, and the company has a website that is not under construction. The company's website address is obtained through the Indonesia Stock Exchange. If the address is not listed on IDX, the data collection process will use a search through the search engine.

Table 1. Sampling Results 


\begin{tabular}{lc}
\hline Criteria & Number of Companies \\
\hline Agricultural companies listed on the IDX until the year 2019 & 22 \\
Agricultural Companies that the website is not accessible & -1 \\
The company did not publish a sustainability report in 2018/2019 & -14 \\
\hline The number of companies that qualify for the criteria & $\mathbf{7}$ \\
\hline
\end{tabular}

These are the seven companies that meet the study's sample requirements and criteria. The companies included in the study are PT Astra Agro Lestari Tbk., PT Austindo Nusantara Jaya Tbk., PT Eagle High Plantations Tbk., PP London Sumatra Indonesia Tb., PT Salim Ivomas Pratama Tbk., PT. Golden Agri-Resource Ltd., and PT Sawit Sumbermas Sarana Tbk. This study will use a qualitative approach in analyzing the narratives from the secondary data from sustainability reporting practices, especially the reports related to environmental issues in effluent and waste, with GRI standards for agricultural companies in Indonesia. The documentation technique will be used in this research as the data collection by collecting company data or documents that are accurate and appropriate.

To achieve the objectives of this study, descriptive-analytical techniques will be used by collecting, presenting and analyzing data related to disclosure of sustainability reports based on GRI standards. Then, qualitative content analysis will be used in this study as an analysis technique. According to Laoli \& Davianti, (2019) qualitative content analysis is an analytical, systematic approach to the guided study of texts in a communication context by following the rules and steps of content analysis. The analysis or logic, i.e., the analysis starts to use specific definitions, then classifies the data based on the parameters, and analyzes the data. Besides, coding sheets will be used as research instruments to analyze the pattern of the narratives presented by the companies observed and as the disclosure item sheets. The coding sheet is expected to have a sufficient level of consistency, validity, and as a guide to analyzing the extent of information disclosed based on the criteria or standard items and GRI reporting guidelines. However, in the context of content analysis, it is more criticized for the existing criteria when obtaining test results (Krippendorff, 2018).

The stages of the data analysis using content analysis based on Eriyanto, (2013) techniques are carried out to achieve the objectives of this study, as follows Stage One: Formulate the Objectives of Analysis. This analysis step aims to analyze the suitability and compatibility of sustainability reports using GRI standards and how to design sustainable reports in Indonesian agricultural companies. This step is done by analyzing the company's sustainability reporting, specifically on the topic of effluent and waste. Second Stage: Conceptualization and Operationalization. This study uses the GRI standard as the analysis concept, precisely the GRI 306 standard on effluent and wastes that the company must disclose. The GRI 306 standard provides guidelines for reporting requirements concerning effluent and waste. This standard can be used by any organization of various sizes, types, sectors, or geographic locations that want to report on the impacts of this topic (GRI, 2016b). GRI 306 standard disclosure is as follows:

Table 2. Global Reporting Initiative About Effluent and Waste

\begin{tabular}{ll}
\hline \multicolumn{1}{c}{ Disclosure of Standard GRI 306 } \\
\hline No & \multicolumn{1}{c}{ Disclosure Topics } \\
\hline 1 & Water discharge by quality and destination \\
2 & Waste by type and disposal method \\
3 & Significant spills \\
5 & Transport of hazardous waste \\
5 & Water bodies affected by water discharges and/or runoff \\
\hline
\end{tabular}

Third Stage: Coding Sheet. This study would use the disclosure item sheet that contains disclosure items as stated in the standard. Meanwhile, to see each sustainability report disclosure item from the research sample, the coding sheet is used as a guide. Hence, coding sheets are not used to measure data quantitatively. Third Stage: Population and Samples. The sample would be 
obtained by utilizing a purposive sampling technique in the population of the Indonesian agricultural companies that go public or are listed on the IDX and have met the criteria established as a sample. Fourth Stage: Data Input. The data of disclosure items will be sorted in the coding sheet based on the keywords and analyzed for the pattern. Fifth Stage: Data analysis, at the last stage, any findings related to GRI Standard items included in the disclosure item sheet will be analyzed based on the existing concepts. This analysis is intended to find out how the disclosure of sustainable reports in the company.

\section{Hasil dan Pembahasan}

\section{Result}

The analysis and discussion of this research were carried out by observing each topic of standard GRI 306, 2016 "Effluents and Waste," namely; disclosure of discharge by quality and destination, waste by type and disposal method, significant spills, transport of hazardous waste, and water bodies affected by water discharges and/or runoff in every company sustainable report. Using keywords that were clarified in the fourth stage of the research methodology, the analysis was helped by the five disclosure categories. The result of the study and discussion of all disclosure is presented below.

\section{Water Discharge}

This disclosure focuses on reporting the volume of water discharge by quality and destination and whether another organization reused the water. The results show only a small number of the total company that has water discharge-related disclosures. This disclosure has been practiced only by three companies, namely, SIMP, LONSUM, and EHP. However, there are differences in the disclosures of each company. The results showed SIMP and LONSUM have two similar points of disclosure: the volume and quality of water discharge. The following are the excerpts taken from these two companies SR interrelated to water discharge: Mill effluent volume: we produced 2,079,788 m3 of wastewater from our 22 certified/audited mills, decrease by 2\% from 2018 levels (2018: 2,128,552 m3). Mill effluent quality: the median Biological Oxygen Demand (BOD) was 2,149 $\mathrm{mg} / \mathrm{l}$ at the 22 mills (2018: 2,590 mg/l) while the median Chemical Oxygen Demand (COD) was 5,951 $\mathrm{mg} / \mathrm{l}$ at the 22 mills (2018: 6,594 mg/l). (SR SIMP $2019 \mathrm{p} \mathrm{46-47)}$

The analysis has shown that the SR disclosures in the two companies for the 2019 observation period have been carried out entirely and in detail. In contrast, the method of disclosure carried out by EHP is inconsistent because EHP only provides a simple description outlined in the form of tables related to quality standards and flow destination. The following is a simple quote from EHP: The company is committed to continuously improving the intensity of water use and the quality of processed wastewater in its operations and ensuring the quality of processed wastewater complies with the quality standards set by the Government. (SR EHP 2018 p 58-59) It is also found that SIMP, LONSUM, and EHP stated that the quality of the water discharge had complied with the quality standards set by the Government. However, there is no disclosure regarding the standard, methodology, and assumptions used by each company. Therefore, the analysis result of the water discharge disclosure topic in the company's sustainability report is still not in accordance with the GRI Standards. This is proven by the fact that only three companies out of seven companies disclose the topic of water discharge. Of the three companies that have disclosures about water discharge, one company is inconsistent in making disclosures, namely EHP. This company has disclosed the topic of water discharge, but the disclosure is only in tabular form without explanation.

\section{Waste by Type and Disposal Method}

Disclosure 306-2 is a standard that focused on the disclosure of waste by type and disposal method, especially; the total weight of hazardous waste, non-hazardous waste, and waste disposal method. Based on all disclosures on GRI standards 306, this topic has been done by all company's sample. It found that seven company samples had reported waste based on the type of hazardous 
waste and non-hazardous waste. Based on the analysis of disclosures 306-2 Waste by Type and Disposal Method presented by the company's sample, the results show that the disclosures on topic 306-2 are still not in accordance with the standard that has been determined. In addition, there are discrepancies in the disclosures in the published reports. Of the seven companies' sample, there are 4 companies that fully disclose topic 306-2 including the reporting of on-site storage. these four companies are SIMP, LONSUM, ASTRA, and ANJ. The following are disclosure quotes from these four companies: At our mills: we produced an average of 1.39 tonnes of hazardous waste in 2019 (2018: 1.85 tonnes). We also produced a total of 2,170 tonnes of non-hazardous waste in 2019 (2018: 1,643 tonnes), $58 \%$ of this waste was sent for recycling while the other $42 \%$ was sent to the landfill. (SR SIMP 2019 p 45).

At our mills: we produced an average of 1.74 tonnes of hazardous waste in 2019 (2018: 2.07 tonnes) At our rubber factories: we produced an average of 2.08 tonnes of hazardous waste in 2019. (SR LONSUM 2019 p 44). Our estates and mills reuse 100\% of milling waste. (SR SIMP 2019 p 45, SR LONSUM $2019 \mathrm{p} \mathrm{44).} \mathrm{Our} \mathrm{solid} \mathrm{waste} \mathrm{and} \mathrm{POME} \mathrm{are} \mathrm{managed} \mathrm{in} \mathrm{compliance} \mathrm{with} \mathrm{regulatory} \mathrm{controls.}$ Mill wastewater, such as POME, is treated on site. An aerated bunker composting system is in place at three mill sites. (SR SIMP 2019 p 46, SR LONSUM 2019 p 44). The Company has been managing its waste effectively, complying with the procedures and regulations stipulated in Government Regulation (PP) No. 101/2014 on Hazardous and Toxic Waste Management. (SR ASTRA 2019 p 77). Detailed data from each type of waste, the weight of processed wastes, and waste treatment are stated in a table of waste management and utilization. (SR ASTRA $2019 \mathrm{p}$ 76). Hazardous and toxic waste is generated from production activities such as used oil, used batteries, and hazardous and toxic-contaminated waste. The company ensures the suitability of the waste profile with the managing company profile and the terms of its processing permit. (SR SSMS 2019 p 120). The company seeks to reduce the quantity of non-hazardous waste/solid waste generated from operational activities through $3 R$ (Reuse, Recycle, Reduce). SSMS has made use of solid waste and liquid waste. (SR SSMS 2019 p 121)

The total weight of waste produced, types of waste, and waste treatment methods are presented in a hazardous and toxic waste management table. (SR SSMS 2019 p 120). Meanwhile, the only company that did not disclose the waste disposal method was EHP. EHP only provides information about the type of waste, how it is used, and the volume of by presented in a table. Therefore, it is still incompatible with the reporting guidelines from disclosure 306-2. The following are disclosure quotes from EHP: Palm Oil Mill Effluent (POME) is reprocessed into liquid fertilizer for land application systems. (SR EHP 2019 p 58). Aside from producing effluent, production activities also produce waste in the form of empty fruit bunch, fiber, palm shell, and waste from processing facilities. The Company carries out regular waste monitoring every month using flow meter. (SR EHP 2019 p 59)

Based on the analysis, it can be seen in the disclosures of the four companies, they have reported topics 306-2 in detail although there were some that are reported in the table. However, another difference found two companies, namely GAR and ANJ, which are not reporting the total weight of the waste produced. The disclosure of these two companies is certainly not in accordance with existing standards. The following are excerpts regarding disclosure of GAR and ANJ: Under our Zero Waste Policy we aim to reuse, recover and recycle. Since 2015, we have achieved 100 percent recycling of waste from the CPO production process in our upstream operations. (SR GAR 2018 p 33). The waste includes solid and liquid waste. We use both types of waste as organic fertilizer and fuel. (SR GAR 2018 p 33). Our downstream waste is disposed of through municipal landfills or incinerators. Hazardous waste is collected for proper disposal by authorized third-parties. (SR GAR 2018 p 33). The process of recycling waste at each CPO production stage is described in a cycle. (SR GAR 2018 p 34)

The liquid waste which is processed in the biogas reactor pond is used as liquid fertilizer for land application in accordance with permits and standards from the Ministry of Environment and Forestry. SMM does not dispose of liquid waste directly in to rivers. (SR ANJ $2019 \mathrm{p} \mathrm{74).} \mathrm{The}$ hazardous and toxic waste is stored on-site in licensed temporary storage facilities. None of this type of waste is reused, recycled, incinerated or goes to landfill. All toxic and hazardous waste is disposed 
of according to the government regulations by ANJ or handled by third parties. (SR ANJ 2019 p 75). Thus, it can be concluded that water disposal has become an important concern for companies. This is shown from the disclosures related to the topic of waste based on the type and method of disposal that have been presented in the sustainability report by all sample companies. However, Although the seven sample companies have reported this disclosure, it is found that there are still inconsistencies in the disclosures of each company.

\section{Significant Spills}

This topic is a standard on GRI 306 that focused on significant spills especially, the locations of spills, the total volume of spills, and the material of spills. For this topic, the analysis finds that a small group of the entire company sample has significant spills-related disclosures. SIMP, LONSUM, and ASTRA are agriculture companies that made the topic of significant spills on their sustainability report. The analysis shows SIMP and LONSUM have relatively the same report content. These two companies stated, there were no spills, fines, sanctions, and complaints against the company regarding the significant spills during 2019. Meanwhile, ASTRA only said there were no spills during 2019. This following are excerpt from SIMP, LONSUM, and Astra: No spills of effluent, CPO, or diesel were recorded in 2019 during harvesting, processing or transportation. No fines or sanctions related to environmental regulations were imposed on SIMP \& LONSUM Group in 2019. No significant environmental related complaints were received from our stakeholders in 2019. (SR SIMP 2019 p 47, SR LONSUM 2019 p 45). During the course of 2019, the Company saw no hazardous and toxic waste spill. (SR ASTRA 2019 p 77). According to the analysis of SR in 2019 from SIMP, LONSUM, and ASTRA, it is found that they did not face any issues related to the topic of significant spills. It also shows the company's procedures were adequately applied.

As a result, it can be concluded that although there are no significant spills occurred during the year, SIMP, LONSUM, and ASTRA still disclosed the topic of significant spill in their SR. Furthermore, it indicates that the companies are open to giving the information even though they didn't have significant spills in 2019. Disclosure of significant spills should be an essential concern for companies because it relates to the environment. If there are significant spills around the company's operations, society can understand how companies handle their problem.

\section{Transport of Hazardous Waste}

Disclosure 306-4 is a standard that focuses on reporting hazardous waste transport, including; the total weight of hazardous waste transported, hazardous waste imported, hazardous waste exported and hazardous waste treated, followed by percentage and standards, methodologies, and assumptions used. In this analysis, it was found that there are four companies namely; SIMP, LONSUM, ASTRA, and SSMS, that reported disclosure 306-4 on their sustainability report. However, these four companies only stated, the hazardous waste will be transported by an accredited third party or the ministry of transportation without providing information regarding the total and percentage weight of hazardous waste. The following are excerpts interrelated with disclosure 306-4: Transportation by third parties, complying with the procedures and regulations stipulated in Government Regulation (PP) No. 101/2014 on Hazardous and Toxic Waste Management. (SR ASTRA $2019 \mathrm{p} \mathrm{77).} \mathrm{100 \%} \mathrm{of} \mathrm{hazardous} \mathrm{waste} \mathrm{is} \mathrm{managed} \mathrm{and} \mathrm{disposed} \mathrm{according} \mathrm{to} \mathrm{national} \mathrm{regulations} \mathrm{and}$ transported by an accredited third-party. (SR SIMP 2019 p 47). 100\% of hazardous waste is managed and disposed according to national regulations and transported by an accredited third-party. (SR LONSUM 2019 p 45). Hazardous and toxic waste is managed by involving third parties who have transportation permits. (SR SSMS 2019 p 119).

Based on the results of the analysis, these four companies only stated, the hazardous waste will be transported by an accredited third party or the ministry of transportation without providing information regarding the total and percentage weight of hazardous waste. From four companies that were reporting disclosure 306-4, it is also found there were no companies that reporting standards, methodologies, and assumptions in their sustainability report. Hence, it is known that the disclosure of the four companies' samples is not in detail and not informative to the reader. 
Therefore, disclosure 306-4 on companies' sustainability report do not comply with the guidelines that the GRI 306 standard has instructed.

\section{Water Bodies Affected by Water Discharges and/or Runoff}

Based on seven sample companies, there was no reporting related to the disclosure of water bodies affected by water discharges and/or runoff which discus about discharges and runoff that affect aquatic ecosystems and have a substantial influence on water supply. It is indicated there are no bodies, related habitat, protected species, or aquatic habitats that are affected by water discharge of company's operation.

\section{Tables and/or Narrative Text from Sustainability Report}

In this research, it was found there are also patterns of disclosure that tend to be different. The disclosure pattern on the Sustainability Report that all companies have done also can be observed using narrative text followed by a table, graph, or cycle as a tool for presenting data and disclosure topics from each company. In contrast, some companies reporting the disclosure topics only with narrative text or vice versa.

Table 3. Company Data Using Tables and/or Narrative text

\begin{tabular}{lccccccc}
\hline Company & SIMP & LONSUM & ASTRA & $\begin{array}{c}\text { EAGLE } \\
\text { HIGH }\end{array}$ & ANJY & SSMS & GAR \\
\hline Narratives and Tables & $\mathrm{V}$ & $\mathrm{V}$ & $\mathrm{V}$ & - & - & $\mathrm{V}$ & $\mathrm{V}$ \\
Narratives Text & - & - & - & - & $\mathrm{V}$ & - & - \\
Tables & - & - & - & $\mathrm{V}$ & - & - & - \\
\hline
\end{tabular}

The analysis shows that companies that provide tables and narratives as complementary information tend to be more transparent in disclosing sustainability reports based on the GRI 306 standard. Meanwhile, for companies that only use tables such as (EHP) or only narrative text such as (ANJ) in their sustainability report, it is feared that the information will cause misunderstanding or misperceptions for the readers.

\section{Disussions}

The results of overall disclosure topics in the GRI standard 306, show that no company made complete disclosure and complied with the reporting guidelines for GRI standard 306. This is shown by looking at the seven companies' sample, almost all of the companies did not fully disclose and comply with the GRI standards 306 . Based on the content analysis method that has been carried out has been found that the topic of disclosure 306-2 (water by type and disposal method) is a topic that all companies have disclosed. However, the pattern of disclosure is still inconsistent. The company's sample does not report some requirements. Nevertheless, overall disclosure of topic 306-2 (water by type and disposal method) has the most detailed content than the other topics. Besides, some topics were made by a small number of companies, namely 306-1 (water discharge by quality and destination), 306-3 (significant spills), and 306-4 (transport of hazardous waste). From five disclosure topics, disclosure 306-5 (Water bodies affected by water discharges and/or runoff) is the only topic that is not in accordance with GRI standard 306.

Based on seven sample companies, only two sample companies, namely SIMP and LONSUM, disclose better than the other sample companies. These two companies have reported most disclosures in the GRI 306 standard or have a disclosure level of $80 \%$ of the total disclosure topics. The disclosure topic not carried out by these two companies is disclosure 306-5 (water bodies affected by discharge and/or water runoff). However, there was no further explanation related to the non-disclosure of this topic. Meanwhile, the other five companies' samples have not disclosed topic 306 in accordance with the 2016 GRI standards. 
According to the analysis by looking at the tables and/or narrative that was provided by companies, it is shown that out of the seven samples of companies, only two companies did not include a table or narrative text as complementary to the disclosure of GRI 306 topics, namely (EHP) and (ANJ). Thus, the two companies tend to be non-transparent which allows for misperception for readers. The results of this study are in line with previous research conducted by Bernard et al., (2015), the GRI standard is not conducive to providing a coherent stakeholder structure, and not all the goals are achieved. According to this study on the seven sample companies, they did not fully disclose the topics on the GRI standard 2016. Therefore, not all company goals are achieved

\section{Simpulan}

This research concluded that the application and compliance of GRI Standard 306 effluent and waste in Indonesia's agriculture companies are relatively low and not yet detailed. From the seven companies' samples, the topic 306-2 most often appears in the company's SR. It shows that companies are less concerned with how their operations can impact the environment, and the application of legitimacy theory "social contract" between communities and companies is not going well. Hence, companies have no encouragement to ensure that their activities and performance acceptable to the communities. Instead, companies can increase their value by utilizing sustainability reports. By publishing sustainability reports, companies can minimize the level of accidents. The stakeholder will respond positively to the companies because nowadays, they are increasingly aware of sustainability reporting in the company. On the other hand, companies can get good reputation from the communities because companies care about the environment. Therefore, it is expected that the company's accountants can make the sustainability reports according to the standard and optimize all disclosures and reflect the actual situation not to mislead report users.

Although the data analysis has been carried out from the researcher's perspective objectively, the researcher's subjectivity cannot be eliminated considering that this research uses content analysis. Also, the data collection process is limited because not all companies have published sustainability reports. As a result, not all data from the observation period are discovered. Furthermore, this study has not found why the sample companies did not disclose several topics and why there are differences in patterns in each sample companies' sustainability reports. For further research, it is expected to increase the level of objectivity by detailing the item disclosure sheet so that the results of the data analysis can be more in-depth, collect data optimally in order to obtain data that is more supportive of data processing, and produces maximum results. It is expected to increase objectivity by detailing the disclosure item sheet so the data analysis results can be more indepth, conduct research on other disclosure topics, and answer the limitations of this study.

\section{Daftar Pustaka}

Alhaj, A. (2019). Sustainability Disclosure on Environmental Reporting: A Review of Literature in Developing Countries. American Based Research Journal, 8(2019-01), 01-13. https://www.researchgate.net/publication/331543249.

Almira, L. F., \& Fuad. (2015). Pengaruh Pengungkapan Sosial dan Lingkungan Terhadap Asimetri Informasi Bagi Investor (Studi Empiris Pada Perusahaan Manufaktur yang Terdaftar di BEI Tahun 2012-2013). Diponegoro Journal of Accounting, 4(4), 541-551. http://ejournals1.undip.ac.id/index.php/accounting.

Amran, A., \& Haniffa, R. (2011). Evidence in Development of Sustainability Reporting: a Case of a Developing Country. Business Strategy and the Environment, 20(3), 141-156. https://doi.org/https://doi.org/10.1002/bse.672.

Bernard, S., Abdelgadir, S., \& Belkhir, L. (2015). Does GRI Reporting Impact Environmental Sustainability? An Industry-Specific Analysis of $\mathrm{CO} 2$ Emissions Performance between Reporting and Non-Reporting Companies. Journal of Sustainable Development, 8(9), 190. 
https://doi.org/10.5539/jsd.v8n9p190.

Berthelot, S., Coulmont, M., \& Serret, V. (2012). Do Investors Value Sustainability Reports? A Canadian Study. Corporate Social Responsibility and Environmental Management, 19(6), 355363. https://doi.org/10.1002/csr.285.

Branco, M. C., \& Rodrigues, L. L. (2006). Communication of Corporate Social Responsibility by Portuguese Banks: A Legitimacy Theory Perspective. Corporate Communications, 11(3), 232248. https://doi.org/10.1108/13563280610680821.

Burhan, A. H. N., \& Rahmanti, W. (2012). the Impact of Sustainability Reporting on Company Performance. Journal of Economics, Business, and Accountancy / Ventura, 15(2), 257-272. https://doi.org/10.14414/jebav.v15i2.79.

Ching, H. Y., Gerab, F., \& Toste, T. H. (2017). The Quality of Sustainability Reports and Corporate Financial Performance: Evidence From Brazilian Listed Companies. SAGE Open, 7(2). https://doi.org/10.1177/2158244017712027.

Eriyanto. (2013). Pengantar Metodologi untuk Penelitian IImu Komunikasi dan IImu-ilmu Sosial Lainnya (Kencana (ed.)). Prenadamedia Group. https://books.google.co.id.

GRI. (2016a). GRI 101: Fundamental 2016. Gssb, 1(1), 30. https://www.globalreporting.org.

GRI, G. R. I. (2016b). GRI 306: Effluents and Waste. GRI Standards, 2016(December), 1-13. https://www.globalreporting.org.

Junior, R. M., \& Best, P. (2017). GRI G4 Content Index: Does It Improve Credibility and Change The Expectation - Performance Gap of GRI-Assured Ustainability Reports? Sustainability Accounting, Management and Policy Journal, 8(5), 571-594. https://doi.org/10.1108/SAMPJ12-2015-0115.

Koesmawardhani, N. W., \& Wardani, H. L. (2017). Hutan Jadi Industri Perkebunan, Orangutan pun Dianggap Hama. DetikNews. https://news.detik.com/berita/d-3447217/hutan-jadi-industriperkebunan-orangutan-pun-dianggap-hama.

Krippendorff, K. (2018). Content Analysis: An Introduction to Its Methodology (Fourth Edi). SAGE Publication, Inc. https://books.google.co.id.

Kurniawan, T., Sofyani, H., \& Rahmawati, E. (2018). Pengungkapan Sustainability Report dan Nilai Perusahan: Studi Empiris di Indonesia dan Singapura. Kompartemen: Jurnal Ilmiah Akuntansi, 16(1), 1-20. https://doi.org/10.30595/kompartemen.v16i1.2100.

Laoli, W. B., \& Davianti, A. (2019). Health and Safety Disclosures Practice in Indonesian Chemical Industries: A Qualitative Content Analysis Study. International Journal of Social Science and Business, 3(4), 348-357. https://doi.org/http://dx.doi.org/10.23887/ijssb.v3i4.21321.

Muryono, S. (2018, September). Warga Menemukan Limbah Pabrik Kelapa Sawit Mengalir ke Sungai. Antara News. https://www.antaranews.com/berita/744360/warga-menemukan-limbahpabrik-kelapa-sawit-mengalir-ke-sungai.

Primadhyta, S., \& Perkasa, A. (2018). Dana "Panas" Sawit Maybank Rp34 T Rusak Hutan Indonesia. CNN Indonesia. https://www.cnnindonesia.com/ekonomi/20180228090606-78279330/dana-panas-sawit-maybank-rp34-t-rusak-hutan-indonesia.

Rosen, M. A. (2017). The Future of Sustainable Development: Welcome to the European Journal of Sustainable Development Research. European Journal of Sustainable Development Research, 1(1), 1-2. https://doi.org/10.20897/ejosdr.201701.

Tarigan, J., \& Semuel, H. (2015). Pengungkapan Sustainability Report dan Kinerja Keuangan. Jurnal Akuntansi Dan Keuangan, 16(2), 88-101. https://doi.org/10.9744/jak.16.2.88-101.

Visser, W., \& Brundtland, G. H. (2013). Our Common Future ('The Brundtland Report'): World Commission on Environment and Development. The Top 50 Sustainability Books, 52-55. https://doi.org/10.9774/gleaf.978-1-907643-44-6_12. 